\title{
Trauma-Induced Nanohydroxyapatite Deposition in Skeletal Muscle is Sufficient to Drive Heterotopic Ossification
}

\author{
Stephanie N. Moore-Lotridge ${ }^{1,5}$ (D) Qiaoli Li ${ }^{7}$ Breanne H. Y. Gibson ${ }^{1,5}$. Joseph T. Martin ${ }^{6}$. Gregory D. Hawley ${ }^{1}$. \\ Thomas H. Arnold ${ }^{1,3}$. Masanori Saito ${ }^{1}$. Sami Tannouri ${ }^{7}$. Herbert S. Schwartz ${ }^{1}$. Richard J. Gumina ${ }^{2,4,5,9}$. \\ Justin M. M. Cates ${ }^{2}$. Jouni Uitto ${ }^{7}$. Jonathan G. Schoenecker ${ }^{1,2,3,5,8}$
}

Received: 27 September 2018 / Accepted: 27 November 2018 / Published online: 4 December 2018

(c) The Author(s) 2018

\begin{abstract}
Heterotopic ossification (HO), or the pathologic formation of bone within soft tissues, is a significant complication following severe injuries as it impairs joint motion and function leading to loss of the ability to perform activities of daily living and pain. While soft tissue injury is a prerequisite of developing HO, the exact molecular pathology leading to trauma-induced HO remains unknown. Through prior investigations aimed at identifying the causative factors of HO, it has been suggested that additional predisposing factors that favor ossification within the injured soft tissues environment are required. Considering that chondrocytes and osteoblasts initiate physiologic bone formation by depositing nanohydroxyapatite crystal into their extracellular environment, we investigated the hypothesis that deposition of nanohydroxyapatite within damaged skeletal muscle is likewise sufficient to predispose skeletal muscle to HO. Using a murine model genetically predisposed to nanohydroxyapatite deposition (ABCC6-deficient mice), we observed that following a focal muscle injury, nanohydroxyapatite was robustly deposited in a gene-dependent manner, yet resolved via macrophage-mediated regression over 28 days post injury. However, if macrophage-mediated regression was inhibited, we observed persistent nanohydroxyapatite that was sufficient to drive the formation of $\mathrm{HO}$ in $4 / 5$ mice examined. Together, these results revealed a new paradigm by suggesting the persistent nanohydroxyapatite, referred to clinically as dystrophic calcification, and $\mathrm{HO}$ may be stages of a pathologic continuum, and not discrete events. As such, if confirmed clinically, these findings support the use of early therapeutic interventions aimed at preventing nanohydroxyapatite as a strategy to evade $\mathrm{HO}$ formation.
\end{abstract}

Keywords Heterotopic ossification · Nanohydroxyapatite $\cdot$ Dystrophic calcification $\cdot$ Skeletal muscle injury $\cdot$ Abcc6

Electronic supplementary material The online version of this article (https://doi.org/10.1007/s00223-018-0502-5) contains supplementary material, which is available to authorized users.

Jonathan G. Schoenecker

Jon.schoenecker@vanderbilt.edu

1 Department of Orthopaedics and Rehabilitation, Vanderbilt University Medical Center, 1215 21st Ave. South, Suite 4200 MCE, South Tower, Nashville, TN 37232, USA

2 Department of Pathology Microbiology and Immunology, Vanderbilt University Medical Center, 1161 21st Ave. South, Nashville, TN 37232, USA

3 Department of Pediatrics, Vanderbilt University Medical Center, 4202 Doctor's Office Tower, 2200 Children's Way, Nashville, TN 37232, USA

4 Division of Cardiovascular Medicine, Vanderbilt University Medical Center, 2220 Pierce Ave, Preston Research Building, Nashville, TN 37232, USA
5 Department of Pharmacology, Vanderbilt University, 2200 Pierce Ave, Robinson Research Building, Nashville, TN 37232, USA

6 College of Arts and Science, Vanderbilt University, 301 Kirkland Hall, Nashville, TN 37240, USA

7 Department of Dermatology and Cutaneous Biology, Sidney Kimmel Medical College, Thomas Jefferson University, 233 South Tenth Street, Bluemle Life Sciences Building, Room 450, Philadelphia, PA 19107, USA

82200 Pierce Ave, Robinson Research Building, Rm 454, Nashville, TN 37232, USA

9 Present Address: University of Nebraska Medical Center, Omaha, NE, USA 


\section{Introduction}

Heterotopic ossification (HO) is the formation of bone within injured soft tissues such as skeletal muscle or tendons. In addition to imposing pain from chronic inflammation and tissue deformation, peri-articular $\mathrm{HO}$ restricts joint mobility and limb function thus precluding activities of daily living $[1,2]$. While reports vary, $\mathrm{HO}$ is a significant problem in the civilian population, particularly following severe injury. For example, up to $25 \%$ of traumatic acetabular fractures, $20 \%$ of spinal cord injuries, and $11 \%$ of brain injuries have been reported to be complicated by $\mathrm{HO}$ development [3-5]. The incidence of $\mathrm{HO}$ dramatically rises in military-related injuries, such that $\mathrm{HO}$ affected up to $65 \%$ of the severe wartime extremity injuries during the Afghanistan and Iraqi conflicts [6]. Although of great significance to both the civilian and military population, the pathophysiology of HO remains poorly understood and, consequently, current treatments are suboptimal. Thus, studies aimed at defining the pathophysiology of $\mathrm{HO}$ to develop novel therapeutic strategies, especially following severe injuries in military populations, are essential.

The majority of soft tissue injuries experienced by patients do not form HO, rather they repair fully to the original tissues form. Failure of tissue repair typically results in fibrosis, devoid of bone. Yet, following traumatic injuries, a subset of patients develops HO. As an explanation to this phenomenon, Chalmers et al. proposed in 1975 that soft tissue injury was a prerequisite of developing $\mathrm{HO}$, and additional predisposing factors that favor ossification within the injured soft tissues environment were available to support bone formation [7]. In support of this theory, it was identified in 2006 that patients and animals with fibrodysplasia ossificans progressiva (FOP), a genetically driven form of $\mathrm{HO}$, possess gain-of-function mutations in the Type 1 bone morphogenic protein (BMP) receptor, which favors cellular transformation within injured soft tissue towards an osteoblast lineage [8,9]. Although these mutations have been demonstrated to be the causative factor in FOP, genome wide association studies have failed to correlate mutations in the BMP signaling pathways with the greater majority of trauma-induced HO [10], suggesting that, in non-FOP cases, alternative predisposing proossification factors may be responsible.

The primary mechanism by which chondrocytes and osteoblasts, two pro-ossification cells, initiate bone mineralization is by stimulating the formation and accumulation of nanohydroxyapatite crystals upon collagen $\mathrm{X}$ and collagen I within their extracellular environment [11]. Importantly, calcium and phosphate circulate at near-saturating concentrations [12] thereby favoring the formation of nanohydroxyapatite by these pro-ossification cells [13].
While these ionic concentrations are ideal for maintaining bone integrity, soft tissue and homeostatic environments are simultaneously exposed to these saturating conditions; thus if a nucleating matrix is available, crystal formation will progress $[12,13]$.

Given the pathologic implications of hardened or mineralized soft tissues, the body possesses a myriad of factors that either prevent or dissolve nanohydroxyapatite [13-29]. One of the most well-described soft tissue protection mechanisms is the production of pyrophosphate (PPi), a potentate anti-mineralization molecule, produced primarily from the cleavage of adenosine triphosphate (ATP) [30, 31]. Thus, in accordance with Chalmers' theory [7], we surmise that if a predisposing ossification factor such as nanohydroxyapatite was not regulated within soft tissues, its deposition could mimic the bone environment and favor ossification. From this scientific premise, we hypothesized that, as an alternative to a gain-of-function of an ossification gene (as seen in FOP), a loss-of-function mutation in the molecular mechanisms that protect soft tissues from nanohydroxyapatite formation may also be sufficient to support $\mathrm{HO}$ following soft tissue injury.

To test this hypothesis, we investigated the fate of skeletal muscle following injury in a murine model of a rare calcification disorder, pseudoxanthoma elasticum (PXE, incidence of 1:50,000). PXE occurs due to biallelic null mutations primarily in Abcc6 (ATP binding cassette sub family C, member 6), an ATP transporter produced in the liver responsible for moving ATP from the intracellular space to the extracellular environment where it is cleaved by ectonucleotide pyrophosphatase/phosphodiesterase 1 (ENPP1) to produce AMP and PPi, a potent inhibitor of nanohydroxyapatite formation. As such, patients and animals with PXE have diminished PPi and develop progressive deposits of nanohydroxyapatite within the skin, cardiovascular system, and retinas [16, 30-35]. Yet, the role of $A b c c 6$ in preventing nanohydroxyapatite and $\mathrm{HO}$ in skeletal muscle following injury is unknown. Here, we investigated two related hypotheses: (1) to determine if a loss of $A b c c 6$ promotes nanohydroxyapatite deposition within injured muscle following injury and (2) if so, whether nanohydroxyapatite deposition in the injured muscle environment is sufficient to promote $\mathrm{HO}$.

\section{Materials and Methods}

\section{Operational Definitions of Soft Tissue Calcification}

The following operational definitions will be utilized throughout in reference to various forms of calcification within skeletal muscle, delineated by their unique morphological properties. (1) Dystrophic calcification will be used broadly to describe deposits of amorphous calcium phosphate crystals within soft tissues. (2) Nanohydroxyapatite 
is a sub-classification of dystrophic calcification that will be utilized to describe calcium phosphate deposits that are both (i) within the nanometer range and (ii) the molecular composition of hydroxyapatite. (3) HO is defined as bone formation in soft tissue, characterized by the presence of woven bone, hematopoietic marrow, and/or the presence of rimming osteoblasts.

\section{Murine Model of Skeletal Muscle Calcification}

Animal Husbandry $A b c c 6^{+/+}, A b c c 6^{+/-}$, and $A b c c 6^{-/-}$mice were housed within Vanderbilt University Medical Center under a 12-h light/dark cycle with free access to food and water. All studies were conducted in 6-week-old animals on a C57BL/6J background fed a standard chow diet. Equal numbers of male and female animals were included in each cohort.

\section{Murine Cardiotoxin-Induced Muscle Injury Model}

Following adequate anesthesia with isoflurane, focal muscle injury was induced via intramuscular injection of $40 \mu \mathrm{L}$ of $10 \mathrm{nM}$ cardiotoxin (Accurate Chemical and Scientific Corp, Westbury, NY) into the posterior compartment of the lower leg using a lateral approach with a $28.5 \mathrm{~g}, 0.5 \mathrm{~mL}$, insulin syringe as previously described $[36,37]$. Both the right and left posterior compartment muscles of the lower extremity were injured and analyzed by radiography for the presence of skeletal muscle calcification.

\section{Output Analysis and Quantification of Skeletal Muscle Calcification}

\section{Radiographic Analysis}

Beginning 7 days post injury (DPI) and continuing through sacrifice, digital radiographs (Faxitron, Tucson, AZ) of the lower extremity were acquired. Following adequate anesthesia, mice were placed in the prone position with hips in abduction, allowing for external rotation of the leg by placing the tibia in a reproducible lateral position. Single plane lateral radiographic images were collected at an exposure of $4 \mathrm{~s}$ at $35 \mathrm{kV}$ and saved as a DICOM (.dcm) files for image processing and quantification.

\section{Soft Tissue Calcification Scoring System (STiCSS) Quantification}

The STiCSS is a previously validated ordinal grading system developed by our lab to quantify the extent of soft tissue calcification within the posterior compartment muscle of the lower extremity longitudinally by serial radiographic analysis [37]. Briefly, the operational definitions of each score are based on the percentage area of soft tissue calcification observed in the posterior compartment of the lower extremity: 0 (0\%), 1 (1-25\%), 2 (25-49\%), 3 (50-75\%), and $4(>75 \%)$.

\section{Micro CT Analysis}

$\mu \mathrm{CT}$ images of the injured hind limbs were acquired following sacrifice at $55 \mathrm{kVp}, 145 \mu \mathrm{A}, 200 \mathrm{~ms}$ integration, 500 projections per $180^{\circ}$ rotation, with a $20 \mu \mathrm{m}$ isotropic voxel size $(\mu C T 40$, Scanco Medical AG, Bassersdorf, Switzerland). After reconstruction, a volume of interest comprising the region of soft tissue calcification within the posterior compartment of the lower extremity was selected as previously described [36]. Mineralized tissue within the volume of interest was segmented from soft tissue using a threshold of 220/1000 (or $450.7 \mathrm{mgHA} / \mathrm{cm}^{3}$ ), a Gaussian noise filter of 0.2 , and support of 1 .

\section{Histological Analysis}

Injured hind limbs were fixed in $10 \%$ neutral-buffered formalin for 24-72 h. All samples were processed in graded series of ethanol, cleared, and embedded in paraffin prior to sectioning. $6-\mu \mathrm{m}$ sections were cut and stained as described below.

Hematoxylin and Eosin (H/E) Staining Deparaffinized sections were stained in Gills 3 hematoxylin solution for $5 \mathrm{~min}$. Slides were rinsed in tap water for $10 \mathrm{~min}$ followed by eosin staining for $2 \mathrm{~min}$. Slides were then dehydrated and cleared in xylene before mounting with Permount. Histological quantification of skeletal muscle damage was assessed by light microscopy at $\times 200$ magnification (Axio imager a1, ZEISS; Oberkochen, Germany) as previously described [36]. At least 3 mice were analyzed per group, with $>2$ sections per mouse and $>4$ images per section (i.e., minimum of 24 images per group). Briefly, skeletal muscle damage was evaluated in a blinded manner by counting (1) 'damaged sarcomeres' identified by hypereosinophilic sarcoplasm and centrally located nuclei, (2) 'calcified sarcomeres' identified by dense basophilic staining for hematoxylin, and (3) histologically normal sarcomeres. These groups were then expressed as a percentage of total muscle fibers within $\times 200$ magnification field.

Von Kossa Staining for Calcification Deparaffinized sections were rinsed with distilled water and exposed to $1 \% \mathrm{AgNO}_{3}$ solution under UV light for $30 \mathrm{~min}$. Slides were counterstained with Fast Green for 5 min, dehydrated, and cleared in xylene before mounting with Permount. 
Martius Scarlet Blue (MSB) Staining Following deparaffinization, staining was performed per standard protocols to assess for fibrin and collagen deposition within damaged tissues. Briefly, deparaffinized sections were rinsed with tap water and stained with Wiegert's Hematoxylin for $5 \mathrm{~min}$. Slides were then rinsed, differentiated in $1 \%$ acid alcohol for $15 \mathrm{~s}$, rinsed again in tap water, and cleared in several changes of $95 \%$ ethanol. Next, slides were placed into working Martius yellow solution for $2 \mathrm{~min}$, rinsed, and stained with Crystal Ponceau 6R for $10 \mathrm{~min}$. Slides were then differentiated in 15 phosphotungstic acid for $5 \mathrm{~min}$, washed, and finally stained with methyl blue solution for $5 \mathrm{~min}$ prior to dehydration through graded ethanol, clearing with xylene, and mounting with Permount.

Immunohistochemical (IHC) Staining of F4/80+Cells IHC for $\mathrm{F} 4 / 80+$ cells indicative of monocyte lineage was performed per standard protocols in a core facility (Vanderbilt Translational Pathology Shared Resource; http://www. mc.vanderbilt.edu/tpsr). \% Area of positive F4/80 staining was quantified by ImageJ through the use of the IHC toolkit freely provided.

\section{Energy Dispersive X-Ray Analysis}

Sections of muscle were analyzed using energy dispersive $\mathrm{X}$-ray (EDS) analysis and topographic mapping. Paraffin sections were mounted onto carbon carriers, imaged, and analyzed for elemental composition with a FEI 600 Quanta FEG scanning electron microscope (FEI Company, Eindhoven, The Netherlands) fitted with an Octane Super SDD EDS detector (EDAX, Sandy, UT, USA). X-ray topographic (RADAR) maps of calcium and phosphorus were acquired using Spirit software version 1.07.05 (Princeton GammaTech, Rocky Hill, NJ, USA). EDS spectra and topographic maps were collected for 60.8 and $717.5 \mathrm{~s}$ (80 frames), respectively.

\section{Macrophage Depletion}

Depletion of macrophages was accomplished through intravenous administration of $200 \mu \mathrm{L}$ of clodronate or PBS-filled (control) liposomes (Liposoma, Amsterdam, The Netherlands) with a $28.5-\mathrm{g}, 0.5-\mathrm{mL}$, insulin syringe weekly beginning at the time of injury until sacrifice $[38,39]$.

\section{Transition Electron Microscopy to Visualize Macrophage-Mediated Dystrophic Calcification Regression}

Specimens were processed for transition electron microscopy (TEM) and imaged in the Vanderbilt cell imaging shared resource-research electron microscopy facility.

\section{Embedding}

Samples were fixed in $2.5 \%$ glutaraldehyde in $0.1 \mathrm{M}$ caco-

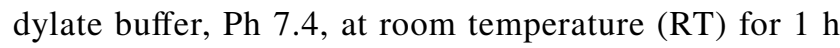
and then transferred to $4{ }^{\circ} \mathrm{C}$, overnight. Samples were washed in $0.1 \mathrm{M}$ cacodylate buffer, incubated for $1 \mathrm{~h}$ in $1 \%$ osmium tetraoxide at RT, and then washed with $0.1 \mathrm{M}$ cacodylate buffer. Subsequently, samples were dehydrated through a graded ethanol series and then 3 exchanges of $100 \%$ ethanol. Next, samples were incubated for $5 \mathrm{~min}$ in $100 \%$ ethanol and propylene oxide (PO) followed by 2 exchanges of pure PO. Samples were then infiltrated with 25\% Epon 812 resin and $75 \%$ PO for $30 \mathrm{~min}$ at RT. Next, samples were infiltrated with Epon 812 resin and PO [1:1] for $1 \mathrm{~h}$ at RT and then overnight at RT. Next day, the samples went through a [3:1] (resin: PO) exchange for 3-4 h, and then incubated with pure epoxy resin overnight. Samples were then incubated in two more changes of pure epoxy resin and then allowed to polymerize at $60{ }^{\circ} \mathrm{C}$ for $48 \mathrm{~h}$.

\section{Sectioning and Imaging}

70-80-nm ultra-thin sections were cut and collected on 200mesh copper grids and post-stained with $2 \%$ uranyl acetate and then with Reynold's lead citrate. Samples were subsequently imaged on the Philips/FEI Tecnai T12 electron microscope at various magnifications.

\section{Statistics and Data Handling}

STiCSS scores between the indicated cohorts were compared using the non-parametric Mann-Whitney or Kruskal-Wallis test with correction for multiple comparisons (Dunn's multiple comparisons test) as previously validated [37]. Error bars represent median with interquartile range. Quantification and statistical analysis of skeletal muscle healing was assessed with a Kruskal-Wallis test with correction for multiple comparisons. $p$ values reported are corrected for multiple comparisons. Statistical analyses were performed in GraphPad Prism (v6, GraphPad Software, La Jolla, CA) with $\alpha=0.05$, and two-sided testing was applied. Number 
of mice $(N)$ per group and number of limbs assessed $(n)$ are reported in the designated figure or figure legend.

\section{Sample Size}

Calculation for sample size was based upon previously published investigations [36, 37]. Previously, we determined that 3 mice per groups were necessary to detect a $100 \%$ change in soft tissue calcification quantified by radiographic analysis. Therefore, all studies were conducted with an excess of 3 mice per group.

\section{Data Collection and Inclusion}

Data from all animal experiments were collected at either 7, 14 , or 28 days post injury as indicated within the figures or figure legends. During these experiments, no animals experience adverse consequences necessitating their removal from the study; therefore, no additional endpoints were assessed. The selected endpoints were previously established, prior to this investigation, with the approval of our animal use protocols. All radiographic data collected were quantified and included within this article. No animals were excluded from the study. Histological results were conducted on a minimum of 3 mice per group, with the image included representing the mean response observed.

\section{Randomization and Blinding}

Once genotyped, all male and female mice from a single litter were randomly assigned to an experimental or treatment group. Mice of different genotypes or treatment group were mixed within each cage. Individuals quantifying weekly radiographic images for the amount of soft tissue calcification were blinded to the genotype or experimental group of the animals. Furthermore, histologic slides were blinded prior to quantification of skeletal muscle regeneration. For studies conducted on high phosphate diet, mice were randomly assigned to each diet groups at the time of weaning. However due to the clear color difference in food, we were not able to blind the diet groups to the investigators obtaining weekly radiographs. Yet, radiographs were quantified by a separate party in a blinded manner.

\section{Results}

\section{Loss of ABCC6 Predisposes Skeletal Muscle to Nanohydroxyapatite Deposition Following Injury}

Utilizing mice with either partial $\left(A b c c 6^{+-}\right)$or complete $\left(A b c c 6^{--}\right)$genetic reduction of ABCC6, we observed a gene-dependent predisposition for dystrophic calcification within the injured skeletal muscle at $7 \mathrm{DPI}$ as measured by radiographic analysis and $\mu \mathrm{CT}$ (Fig. 1a and b; Table 1). Further analysis by energy dispersive X-ray (EDS) and histologic analysis demonstrated that the dystrophic calcification present within damaged skeletal muscle was in the nanometer range and possessed both inorganic calcium and phosphate with an average calcium/phosphate atomic ratio of $1.67 \pm 0.2$, indicative of nanohydroxyapatite (Fig. 1c). Together, these results demonstrate that loss of ABCC6 is sufficient to predispose skeletal muscle, like other soft tissues, to the deposition of nanohydroxyapatite following injury.

\section{Nanohydroxyapatite Deposited in Skeletal Muscle Following Injury is Reversible}

Given the above findings, we next examined the second hypothesis that nanohydroxyapatite deposited within skeletal muscle following injury would be sufficient to promote HO. Longitudinal radiographic analysis of Abcc6-deficient mice demonstrated robust nanohydroxyapatite depositing within injured tissues at 7 DPI that progressively decreased in both $A b c c \sigma^{+/-}$and $A b c c 6^{-1-}$ mice over 28 DPI (Fig. 2a). Histological quantification of damaged skeletal muscle at 7 and 28 DPI in $\mathrm{Abcc}^{+/+}, \mathrm{Abcc}^{+/-}$, and $\mathrm{Abcc6}^{-/-}$demonstrated comparable initial levels of injury between cohorts, given the comparable percentage of histologically normal sarcomeres, and confirmed the decrease of nanohydroxyapatite in $A b c c 6^{+-}$and $A b c c 6^{-/-}$between 7 and 28 DPI (Fig. 2b; Table 2). Taken together, while loss of ABCC6 is sufficient to predispose skeletal muscle to nanohydroxyapatite deposition at 7 DPI, the mineral deposited was progressively removed from the damaged skeletal muscle and therefore was insufficient to promote ossification.

\section{Macrophages Mediate Nanohydroxyapatite Resorption from Damaged Skeletal Muscle}

Given the progressive decrease in nanohydroxyapatite from damaged skeletal muscle over 28 DPI, we next investigated (1) the mechanisms by which nanohydroxyapatite was degraded and (2) the pathologic consequence of impaired nanohydroxyapatite degradation on skeletal muscle healing.

Previously, macrophages have been suggested to assist in the resorption of calcification in vitro and within the cardiovascular system, yet it is unknown what role macrophage plays in regression of nanohydroxyapatite deposited in skeletal muscle. Here, histological analysis of $A b c c \sigma^{+/-}$and $A b c c \sigma^{-1-}$ injured skeletal muscle demonstrated foci of nanohydroxyapatite surrounded by a cellular inflammatory infiltrate consisting of $\mathrm{F} 4 / 80+$ macrophages/monocytes. This infiltrate was present at 7 DPI and persisted through 28 DPI, where it was largely 

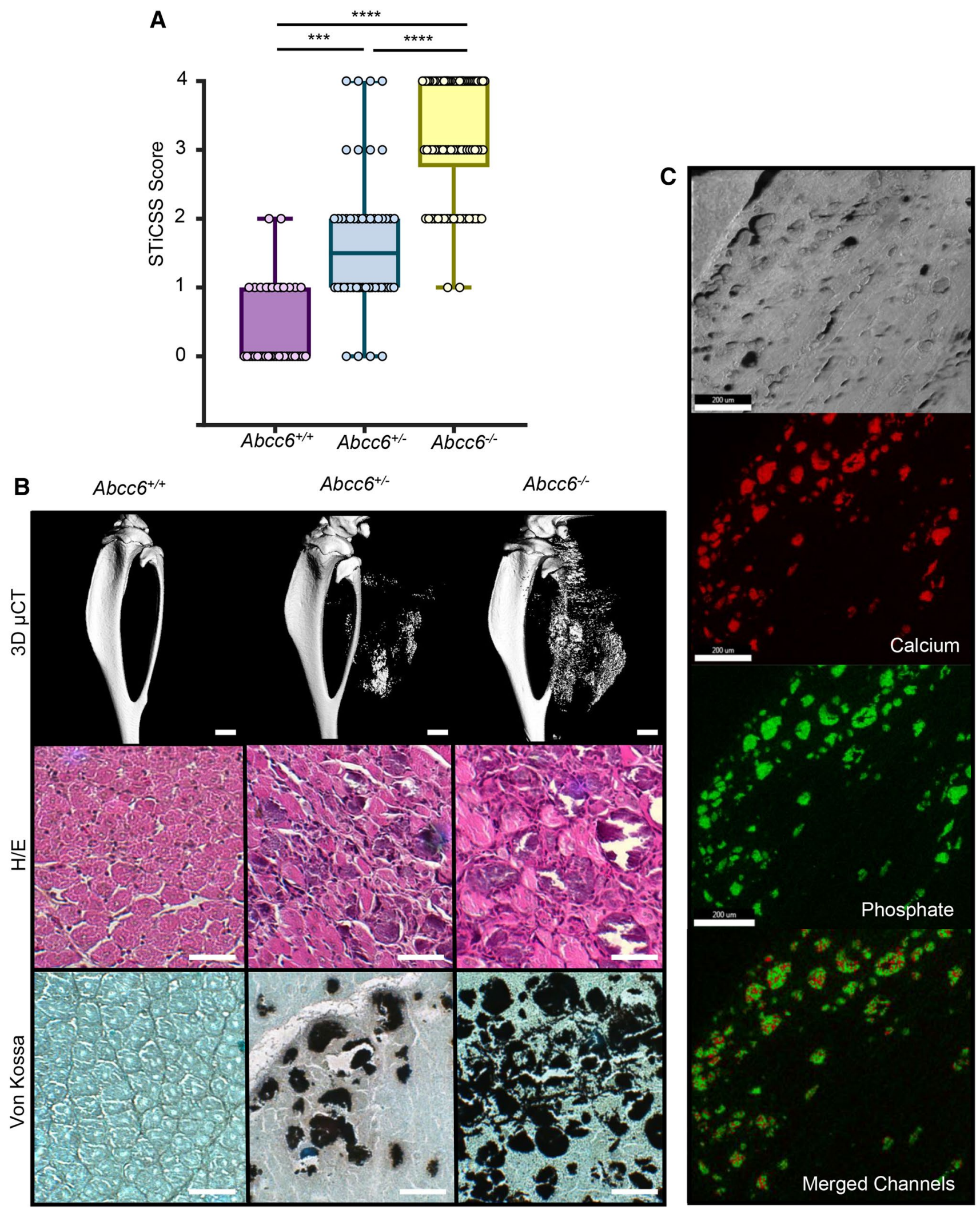

focused around the remaining sites of nanohydroxyapatite (Fig. 3a). When quantified, the $\%$ area of positive F4/80 staining increased in a gene-dependently at both 7 and
28 DPI (Suppl Fig. 1), aligning with the gene-dependent levels of calcification observed previously by radiographic and histologic analysis (Figs. 1,2) Transition 
4Fig. 1 Loss of ABCC6 predisposes skeletal muscle to nanohydroxyapatite deposition at 7DPI. a WT $\left(A b c c 6^{+/+}\right)$, heterozygous $\left(A b c c 6^{+/-}\right)$, and homozygous $\left(A b c c 6^{-1-}\right)$ mice were assessed for calcification at the site of skeletal muscle injury by radiographic analysis and subsequent STiCSS quantification at 7 DPI. See Table 2 for detailed analysis of the genotypes and N. ***p $<<0.001$; $* * * * p<0.0001$. Statistical analysis between groups was performed using a non-parametric Mann-Whitney test. b Representative 3D $\mu \mathrm{CT}$ reconstructions and histological analysis of skeletal muscle calcification within the injured gastrocnemius and soleus muscles at 7 DPI. Scale bar represents $100 \mu \mathrm{m}$. $n \geq 3$ mice per genotype. Positive Von Kossa staining, noted by the black deposits, indicates calcium deposition within the damaged skeletal muscle. c Energy dispersive X-ray (EDS) analysis of dystrophic calcification nodules within damaged ABCC6-deficient skeletal muscle at 14 DPI. Topographic mapping demonstrated marked co-localization of calcium and phosphate with an average calcium/phosphate atomic ratio of $1.67 \pm 0.2$, indicative of hydroxyapatite. Analysis was conducted following random sampling of 5 distinct spots per tissue section. Scale bar represents $200 \mu \mathrm{M}$, thereby indicating nanohydroxyapatite

electron microscopy of injured skeletal muscle revealed macrophages adjacent to damaged sarcomeres containing dense encapsulated granules, indicative of resorbed nanohydroxyapatite (Fig. 3b). Furthermore, when macrophages were inhibited in either $A b c c \sigma^{+/-}$- or $A b c c \sigma^{-1-}$ deficient animals via liposome-targeted clodronate administration, we observed significant inhibition of nanohydroxyapatite resorption through 28 DPI compared to control-treated animals (Fig. $3 \mathrm{c}$ and d). Taken together, these data suggest that macrophages are present within damaged tissues and are participating in the resorption of nanohydroxyapatite from damaged skeletal muscle.

\section{Pathologic Consequence of Impaired Nanohydroxyapatite Resorption}

Histological analysis of $A b c c 6^{+/-}$tissue at 28 DPI demonstrated that while both cohorts of mice developed nanohydroxyapatite, in mice lacking macrophage-mediated resorption, nanohydroxyapatite was persistent in $5 / 5$ mice and sufficient to support $\mathrm{HO}$ in 4/5 mice analyzed, characterized by the presence of woven bone and central hematopoiesis (Fig. 3d and e, Supp Figs. 2 and 3). Detailed assessment of these regions demonstrated small focal areas morphologically akin to $\mathrm{HO}$ as well as regions that appear to be nanohydroxyapatite transitioning to ossified lesions (Fig. 3f-yellow arrows). Together, these data suggest that (1) macrophages are an essential cellular mediator, capable of regressing nanohydroxyapatite from damaged skeletal muscle, and (2) if macrophages are inhibited, persistent nanohydroxyapatite within damaged tissues is sufficient to predispose damaged skeletal muscle to HO formation.

\section{Discussion and Conclusions}

Since proposed by Chalmers in 1975 [7], the theory that HO requires a pro-ossification stimulus within an injured soft tissue environment has been maintained. This theory supported the search for gain-of-function mutations in soft tissues, such as those found in the BMP pathway (i.e., FOP), responsible for cellular transformation of soft tissue cells into bone-forming cells. Here, we demonstrate that a loss-of-function mutation in the cellular machinery designed to protect soft tissue from nanohydroxyapatite deposition is an additional mechanism through which $\mathrm{HO}$ can form following soft tissue injury. Interestingly, we observed that as a contingency plan to the primary soft tissue protection mechanisms, macrophages efficiently resorbed nanohydroxyapatite immediately prior to myogenesis. In the absence of both synergistic soft tissue protection mechanisms (loss of both Abcc6 and macrophage resorption), $\mathrm{HO}$ ensued. These findings support a potential additional paradigm in $\mathrm{HO}$ which can result from insufficient protection against nanohydroxyapatite with a subsequent failure of macrophage-mediated resorption (Fig. 4).
Table 1 Quantification of skeletal muscle calcification in ABCC6-deficient mice at 7DPI

\begin{tabular}{|c|c|c|c|c|c|c|}
\hline \multirow[t]{2}{*}{ STiCSS score } & \multicolumn{2}{|l|}{$\mathrm{ABCC}^{+/+}$} & \multicolumn{2}{|l|}{$\mathrm{ABCC}^{+/-}$} & \multicolumn{2}{|l|}{$\mathrm{ABCC}^{-/-}$} \\
\hline & $N$ & $\%$ & $N$ & $\%$ & $N$ & $\%$ \\
\hline 0 & 43 & 67.2 & 4 & 7.7 & 0 & 0 \\
\hline 1 & 20 & 31.3 & 22 & 42.3 & 2 & 2.3 \\
\hline 2 & 1 & 1.5 & 18 & 34.6 & 19 & 22.1 \\
\hline 3 & 0 & 0 & 4 & 7.7 & 23 & 26.7 \\
\hline 4 & 0 & 0 & 4 & 7.7 & 42 & 48.9 \\
\hline$N(n)$ & 64 (32 mice) & & 52 (26 mice) & & 86 (43 mice) & \\
\hline Median & 0.0 & & 1.5 & & 3.0 & \\
\hline
\end{tabular}

$N$ represents total number of individual samples analyzed, with the left and right leg acting as individual samples. $n$ represents total number of mice per group. Equal number of male and females was used in each genotype 
Nanohydroxyapatite deposition within soft tissues can occur from a variety of risk factors, including both genetic and environmental (i.e., high phosphate diet) sources [13-29]. Here, we observed for the first time that genetic loss of Abcc6 lead to robust deposition of nanohydroxyapatite within damaged muscle. These findings support a potential role for Abcc6 in preventing aberrant mineralization in skeletal muscle, much akin to its activity in other soft tissues such as the skin, kidney, and cardiovascular system [16, 24, 40-43]. Furthermore, while homozygous null mutations in Abcc6 have been linked to rare calcification disorders, such as PXE, we observed that even a partial loss $\left(A b c c 6^{+-}\right)$was sufficient to predispose skeletal muscle to nanohydroxyapatite deposition following injury. While loss-of-function
Fig. 2 Nanohydroxyapatite deposition in ABCC6-Deficient Mice is Degraded Over 28 DPI. Beginning at 7DPI, $\mathrm{Abcc6}^{+/+}$, $A b c c 6^{+/-}$, or $A b c c 6^{-1-}$ animals were a assessed weekly by radiographic analysis through 28 DPI and quantified by the STiCCS, to reveal progressive resolution of nanohydroxyapatite from damaged skeletal muscle. b 3D $\mu \mathrm{CT}$ and histologic analysis at 28 DPI demonstrates reduced nanohydroxyapatite deposition compared to results seen in $7 \mathrm{DPI}$. H/E staining was utilized to assess sarcomere morphology and regeneration quantified in Table 2, and Von Kossa Staining was used to visualize calcification. Scale bar represents $100 \mu \mathrm{m} . n \geq 3$ mice per genotype

\section{A}

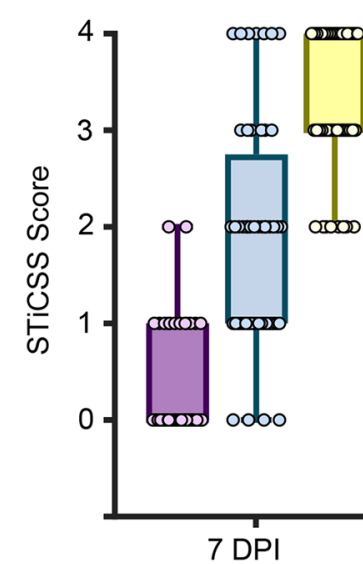

$7 \mathrm{DPI}$

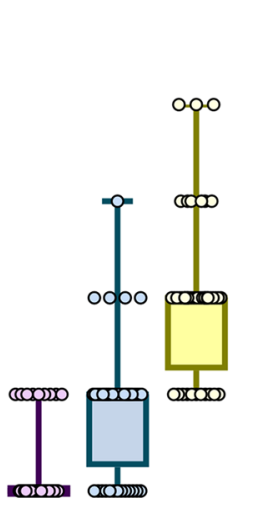

$21 \mathrm{DPI}$

$A b c c 6^{+/-}$

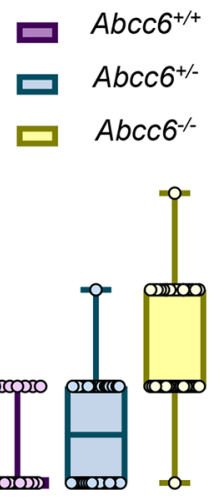

다 $\mathrm{Abc6}^{+/+}$

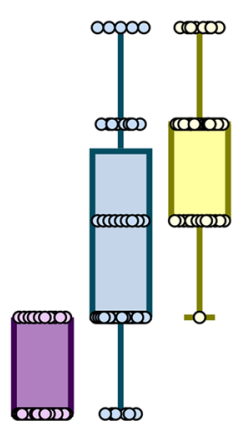

14 DPI

B $\quad \mathrm{Abcc6}^{+/+} \quad \mathrm{Abcc6}^{+/-} \quad \mathrm{Abcc6}^{-1}$

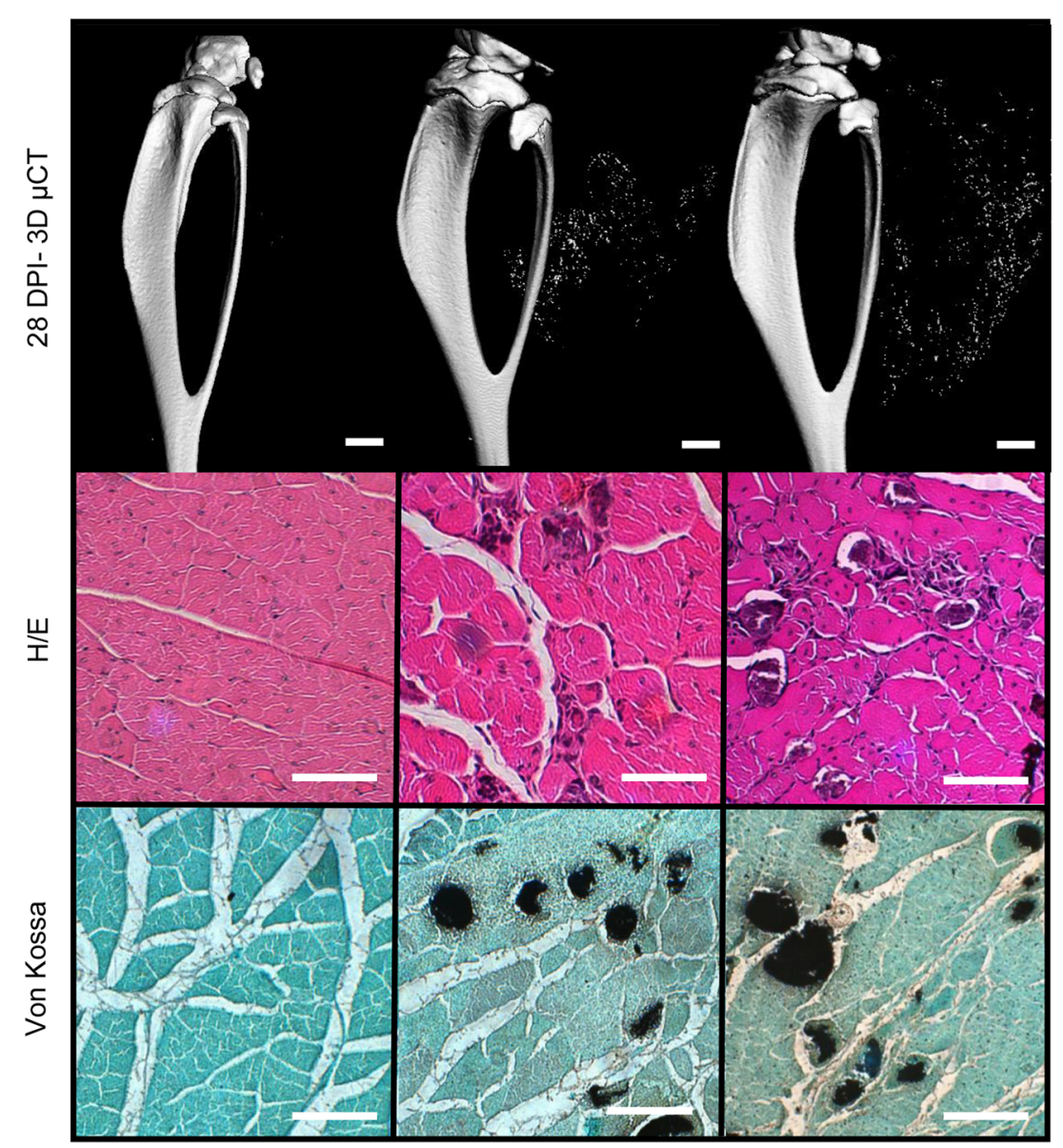


mutations of $A b c c 6$ such as those seen in PXE are rare (1:50,000), an estimated 1:150-1:300 individuals are carriers for pathologic mutations in Abcc6 [44]. Our results do not suggest that all individuals with either partial or biallelic pathologic mutation in $A b c c 6$ will develop HO, but they rather suggest that these individuals may be at risk for the formation nanohydroxyapatite within damaged soft tissue, which may predispose damaged skeletal muscle to ossification if persistent. Furthermore, considering that severely injured patients prone to $\mathrm{HO}$ formation have been reported independently to experience both deposits of dystrophic calcification and failure of macrophage function [45-52], these findings together demonstrate the plausibility for this new loss-of-function paradigm of $\mathrm{HO}$.

The molecular mechanisms through which ABCC6 prevents mineralized of soft tissues are not completely understood. Various groups have provided evidence that alteration to either adenosine [53-56] and/or pyrophosphate production $[16,31,57]$ is responsible for the aberrant calcification observed in ABCC6-deficient animal models and patients with PXE. While Abcc6-deficient animals develop robust skeletal muscle calcification, preliminary studies utilizing animals deficient in either CD73 or CD39, two critical components of adenosine production, demonstrated minimal skeletal calcification skin to wildtype animals following injury (data not shown) (Fig. 4). These findings suggest that reduced adenosine production [58] does not predispose skeletal muscle to nanohydroxyapatite deposition. Therefore, given the numerous reports of reduced circulating PPi levels in patients with PXE and
ABCC6-deficient mice [31,33-35] and recent reports of successful administration of oral PPi to inhibit connective tissue calcification in an ABCC6-deficient murine model [59], these results together suggest that PPi production and its presence in circulation may be responsible for protecting skeletal muscle from calcification following injury. As pyrophosphate levels were not directly measured in this study, further biochemical and enzymatic investigations will be necessary to confirm PPi direct role in protecting skeletal muscle from trauma-induced calcification.

Regardless of the mechanism, the loss of Abcc6 resulted in robust deposition of nanohydroxyapatite in the injured muscle. However, against our hypothesis, the presence of nanohydroxyapatite did not result in HO. Instead, we observed that macrophages resorb the injury-induced nanohydroxyapatite and muscle repair ensues. The essential role of macrophages in this process is highlighted by our experiments in which macrophages were eliminated using liposome-clodronate. In these experiments, not only did the nanohydroxyapatite deposition persist, but ossification ensued.

These findings are transformative in regard to the role of macrophages in HO. The presence of macrophages and inflammation within damaged skeletal muscle has long been observed, both clinically and in basic science investigations. Although debated, currently, macrophages are thought to be a driving factor of HO pathophysiology. For example, in murine models of FOP, it has been demonstrated that depletion of macrophages reduces $\mathrm{HO}$ in this model by $\sim 50 \%$ [60]. Furthermore, in a preclinical model of neurological
Table 2 Histological quantification of skeletal muscle calcification and regeneration at 7 and 28 DPI

\begin{tabular}{lllllc}
\hline Genotype (timepoint) & $N$ & $\begin{array}{l}\text { \% Histologically } \\
\text { normal sarcomes }\end{array}$ & Regenerating sarcomeres & $\begin{array}{c}\text { Calcified or dam- } \\
\text { aged sarcomeres }\end{array}$ \\
\hline $\mathrm{ABCC6}^{+/+}$ & 7 DPI & 8 & $26.53 \pm 15.31^{\mathrm{a}}$ & $72.40 \pm 15.30$ & $1.07 \pm 1.92$ \\
$\mathrm{ABCC6}^{+/-}$ & 7 DPI & 8 & $18.81 \pm 11.51^{\mathrm{a}}$ & $56.92 \pm 15.95$ & $24.27 \pm 15.24^{\mathrm{d}, \mathrm{e}}$ \\
$\mathrm{ABCC6}^{-/-}$ & 7 DPI & 11 & $18.50 \pm 13.71^{\mathrm{a}}$ & $43.44 \pm 11.07^{\mathrm{c}}$ & $38.06 \pm 15.84^{\mathrm{f}}$ \\
$\mathrm{ABCC6}^{+/+}$ & $28 \mathrm{DPI}$ & 6 & $42.20 \pm 17.67^{\mathrm{b}}$ & $57.45 \pm 18.18$ & $0.35 \pm 0.86^{\mathrm{g}}$ \\
$\mathrm{ABCC6}^{+/-}$ & $28 \mathrm{DPI}$ & 13 & $39.37 \pm 16.81^{\mathrm{b}}$ & $54.78 \pm 16.85$ & $5.82 \pm 3.64^{\mathrm{h}}$ \\
$\mathrm{ABCC6}^{-/-}$ & $28 \mathrm{DPI}$ & 13 & $31.47 \pm 10.53^{\mathrm{b}}$ & $51.78 \pm 11.78$ & $16.75 \pm 4.89^{\mathrm{i}}$ \\
\hline
\end{tabular}

Detailed histological analysis of $\mathrm{Abcc}^{+/+}, \mathrm{Abcc}^{+/-}$, and $A b c c 6^{-/-}$mice at 7 and 28 DPI. $N$ number of individuals analyzed per time point, mixed between males and females. Four sections per mouse and four images per section were analyzed as outline in Materials and Methods section

${ }^{a}$ Non-significant difference between groups, $p>0.05$

${ }^{\mathrm{b}}$ Non-significant difference between groups, $p>0.05$

${ }^{\mathrm{c}} \mathrm{Abcc6}^{+/+}$versus $\mathrm{Abcc6}^{-/-}$, **, $p=0.001$

${ }^{\mathrm{d}} \mathrm{Abcc6}^{+/+}$versus $\mathrm{Abcc6}^{+/-}, * * * p=0.0001$

${ }^{\mathrm{e}} \mathrm{Abcc6}^{+/-}$versus $\mathrm{Abcc6}^{-/-}, * p=0.028$

${ }^{\mathrm{f}} \mathrm{Abcc6}^{+/+}$versus $\mathrm{Abcc6} 6^{-/-}, * * * * p<0.0001$

${ }^{\mathrm{g}} \mathrm{Abcc} 6^{+/+} 7$ versus 28 DPI, non-significant difference, $p>0.05$

${ }^{\mathrm{h}} \mathrm{Abcc}^{+/-} 7$ versus 28 DPI, $* * * p=0.0007$

${ }^{\mathrm{i}} \mathrm{Abcc6}^{-/-} 7$ versus $28 \mathrm{DPI}, * * * * p<0.0001$ 

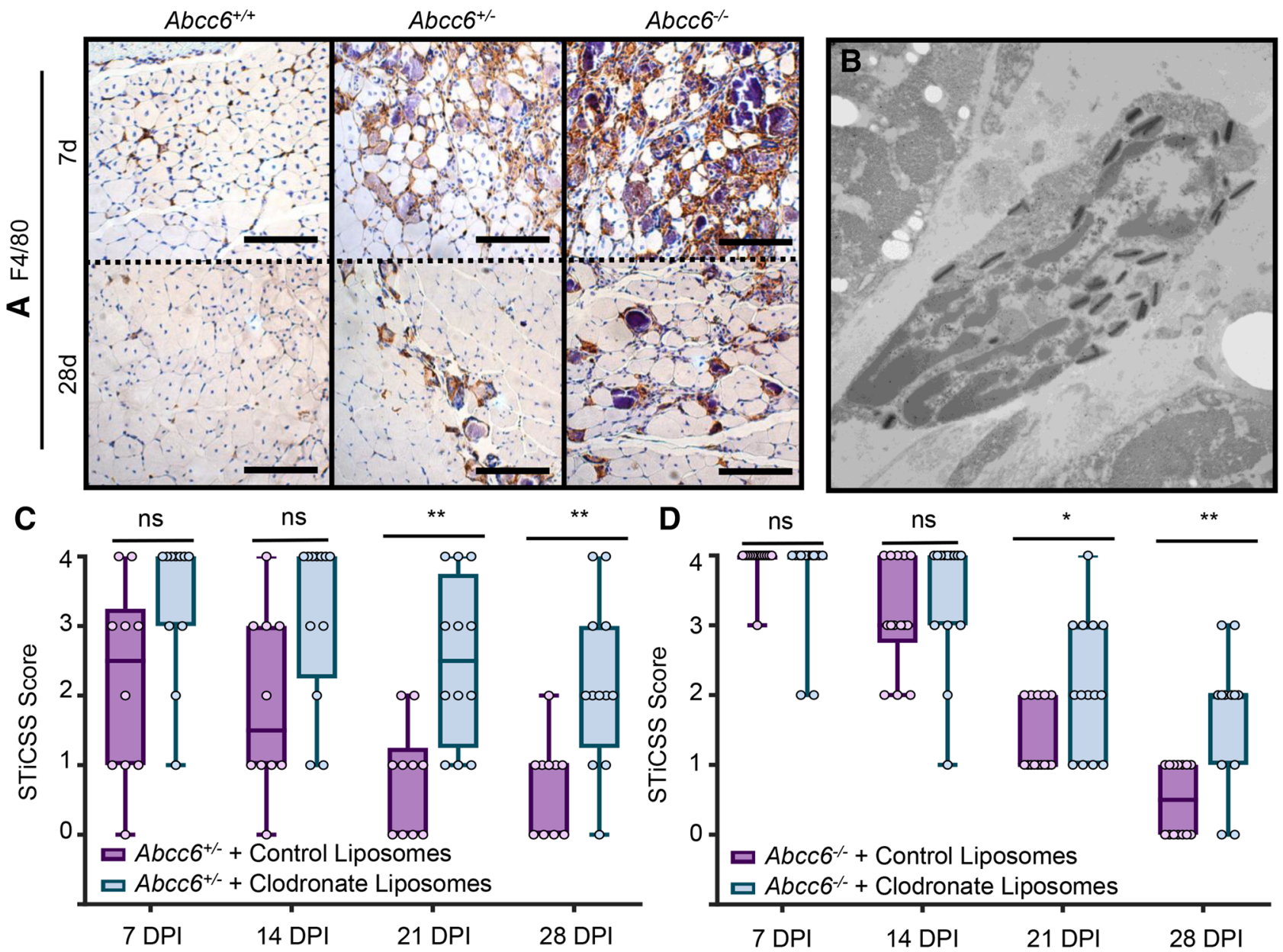

a Abcc6 $^{-/}+$Control Liposomes

口 $A b c c 6^{-/}+$Clodronate Liposomes

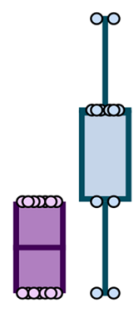

$\mathrm{Abcc6}^{+/-}$with Clodronate Liposomes
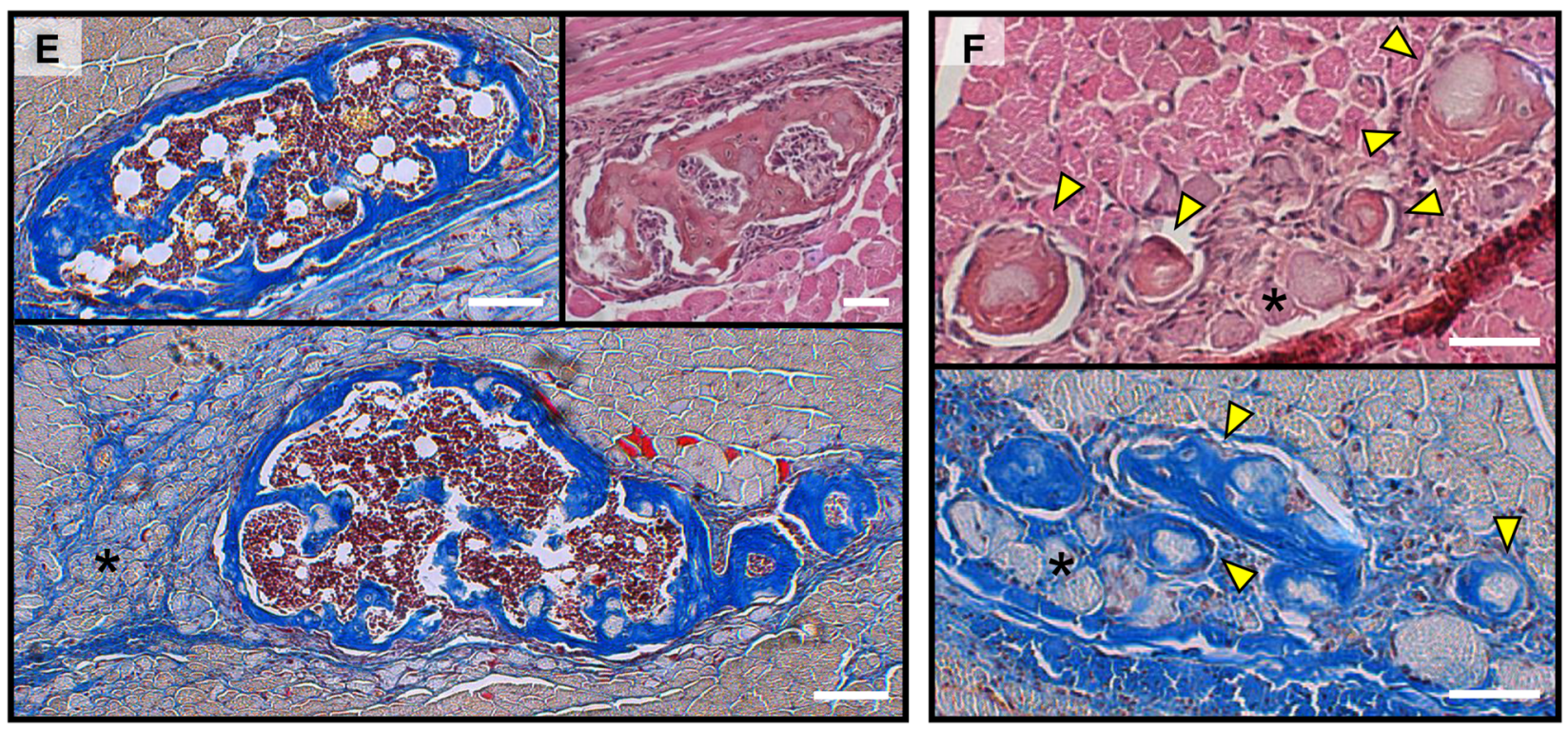
4Fig. 3 Macrophage-mediated resolution of nanohydroxyapatite prevents maturation to HO. a Immunohistochemical stain for $\mathrm{F} 4 / 80+$ cells at 7 and $28 \mathrm{DPI}$ in injure skeletal muscle from $A b c c 6^{+/+}$, $A b c c 6^{+/-}$, or $A b c c 6^{-/-}$mice. b Transition electron microscope image of a macrophage containing phagocytosed nanohydroxyapatite. Scale bar represents $500 \mathrm{~nm}$. Image was obtained from a WT C57BL/6J following CTX injury at 3 days post injury when macrophage infiltration to damaged tissue is greatest [36]. c Longitudinal STiCSS analysis of $\mathrm{Abcc}^{+/-}$treated with either control (PBS) or clodronatefilled liposomes beginning at the time of injury. $N \geq 5$ mice per group. Nanohydroxyapatite was not observed in $A b c c \sigma^{+/+}$mice treated with either control or clodronate-filled liposomes, $N \geq 4$ mice per group. Data not shown. $* * p<0.01$; ***p $<0.001$. d MSB histological analysis at 28 DPI of $A b c c \sigma^{+/-}$mice treated with control liposomes. e, $\mathbf{f}$ Histological analysis of $A b c c \sigma^{+/-}$mice treated with clodronate-containing liposomes indicating the presence of mature HO (E, MSB, and $\mathrm{H} / \mathrm{E}$ ) characterized by the presence of woven bone, blue staining (MSB) indicative of collagen deposition, and central hematopoiesis. Regions of persistent nanohydroxyapatite (black asterisks), and regions that appear to be nanohydroxyapatite maturing to ossified lesions (F-Yellow arrows, MSB, and H/E) were also observed. Scale bar represents $100 \mu \mathrm{m}$

HO it was observed that ablation of macrophages reduced the size of HO by $90 \%$ [61]. Therefore, while macrophages have been demonstrated to be essential for tissue repair, they dichotomously can promote the inflammatory state, as observed in prior HO studies and conditions such as rheumatoid arthritis. Therefore, when we began our investigations, we recognized that macrophages may or may not be beneficial for proper tissue repair following the deposition of nanohydroxyapatite. Through using the same techniques of macrophage ablation of prior $\mathrm{HO}$ studies, our results clearly demonstrated that the macrophages stimulated by injury and nanohydroxyapatite deposition function positively to get rid tissues of dystrophic calcification, thereby preventing subsequent HO.

While prior results seem contradictory to our findings, neither of these previous HO models have been demonstrated to progress through a nanohydroxyapatite precursor. Therefore, we propose that the role of macrophages in $\mathrm{HO}$ is variable and rather may be dependent upon the environment the macrophages encounter within the damaged tissue. In support of this theory, prior reports have demonstrated that macrophage-mediated regression of calcification is size and composition dependent. If in the nanometer range, macrophages can effectively phagocytose small hydroxyapatite crystals, such as those found in dystrophic calcification lesions, yet, if particles grow beyond $10 \mu \mathrm{m}$, they become difficult for a single macrophage to phagocytose [13, 62]. Like size, the composition of calcification greatly impacts the macrophage phenotype and phagocytosis abilities. If the organic components of bone are present (i.e., collage fibrils), macrophage binding and subsequent phagocytosis is inhibited [63]. Moreover, recent investigations by VillaBellosta et al. have demonstrated in vitro that macrophages in the presence of high levels of phosphate adopt a M2-like phenotype and expresses elevated anti-mineralization activity dependent upon PPi production [64, 65]. Aligning these findings with our in vivo observations, we propose that when the macrophages encounter nanohydroxyapatite deposits within the injured skeletal muscle, the M2-like macrophages (or reparative macrophages) can respond to this calcium phosphate-rich environment, and adjust their phenotype to promote anti-mineralization activity and clearance of the calcific deposits. To investigate this hypothesis, further investigation into the phenotype of macrophages surrounding the nanohydroxyapatite deposits is warranted. Together, these findings demonstrated that the role of macrophages in $\mathrm{HO}$ is potentially more dichotomous than previously believed, and thus caution should be raised when considering therapeutics aimed at inhibiting macrophages for treating $\mathrm{HO}$, prior to determining whether the macrophages is a driver or protector for $\mathrm{HO}$ in that particular pathologic state.

Previously, our laboratory demonstrated that plasmin (a powerful reparative protease) like ABCC6 protects skeletal muscle from the formation of dystrophic calcification following injury [36] (Fig. 4). Yet, plasmin has many additional roles during tissue repair, one of which is promotion of macrophage activity and migration. As such, in plasminogendeficient mice, we previously observed the formation of dystrophic calcification which persisted over 28 DPI and developed in HO. This observation provided the foundation for the theory that dystrophic calcification and $\mathrm{HO}$, rather than being dichotomous pathologies, may rather be part of the same pathologic continuum. However, given plasmin's variable roles in tissue repair, we necessitated an additional model to isolate specific steps of the pathologic continuum. The studies presented within represent the use of ABCC6 as a directed model to examine the pathologic continuum of dystrophic calcification to HO. Aligning with the results observed in plasmin-deficient animals, utilizing an isolated model, we found that the formation of dystrophic calcification, if persistent due to reduced macrophage-mediated regression, is sufficient to drive $\mathrm{HO}$.

In summary, these foundational studies reveal a potential new paradigm in $\mathrm{HO}$, where persistent nanohydroxyapatite within damaged skeletal muscle as a result of a loss-of-function mutation, in conjunction with a failure of macrophagemediated resorption, is sufficient to support HO. If found to be clinically valid, this paradigm suggests that rather than being dichotomous pathologies, nanohydroxyapatite formation and HO may be part of the same pathologic continuum, thus providing a novel therapeutic advantage given that nanohydroxyapatite, unlike mature bone, can be resorbed from the damaged tissues. Furthermore, as current treatment regimens for $\mathrm{HO}$, such as prophylactic drugs and radiation therapy, are focused on preventing bone formation, they 
Fig. 4 The "Two Hit" mechanism of HO formation: taken together with previous studies [36], our results suggest that nanohydroxyapatite can deposit with in skeletal muscle following injury if one of the skeletal muscle protection mechanisms (i.e., ABCC6 or plasmin) are insufficient. Fortunately, the body possesses a secondary macrophage-mediated cleanup crew to regress nanohydroxyapatite from damaged tissues, thereby resolving the predisposing factors to $\mathrm{HO}$ formation. Together, these two lines of defense are critical for preventing nanohydroxyapatite deposition within damaged tissues and its subsequent maturation to HO. These findings suggest a new paradigm for $\mathrm{HO}$ formation in which $\mathrm{HO}$ can result from insufficient protection against nanohydroxyapatite with a failure of macrophagemediated regression

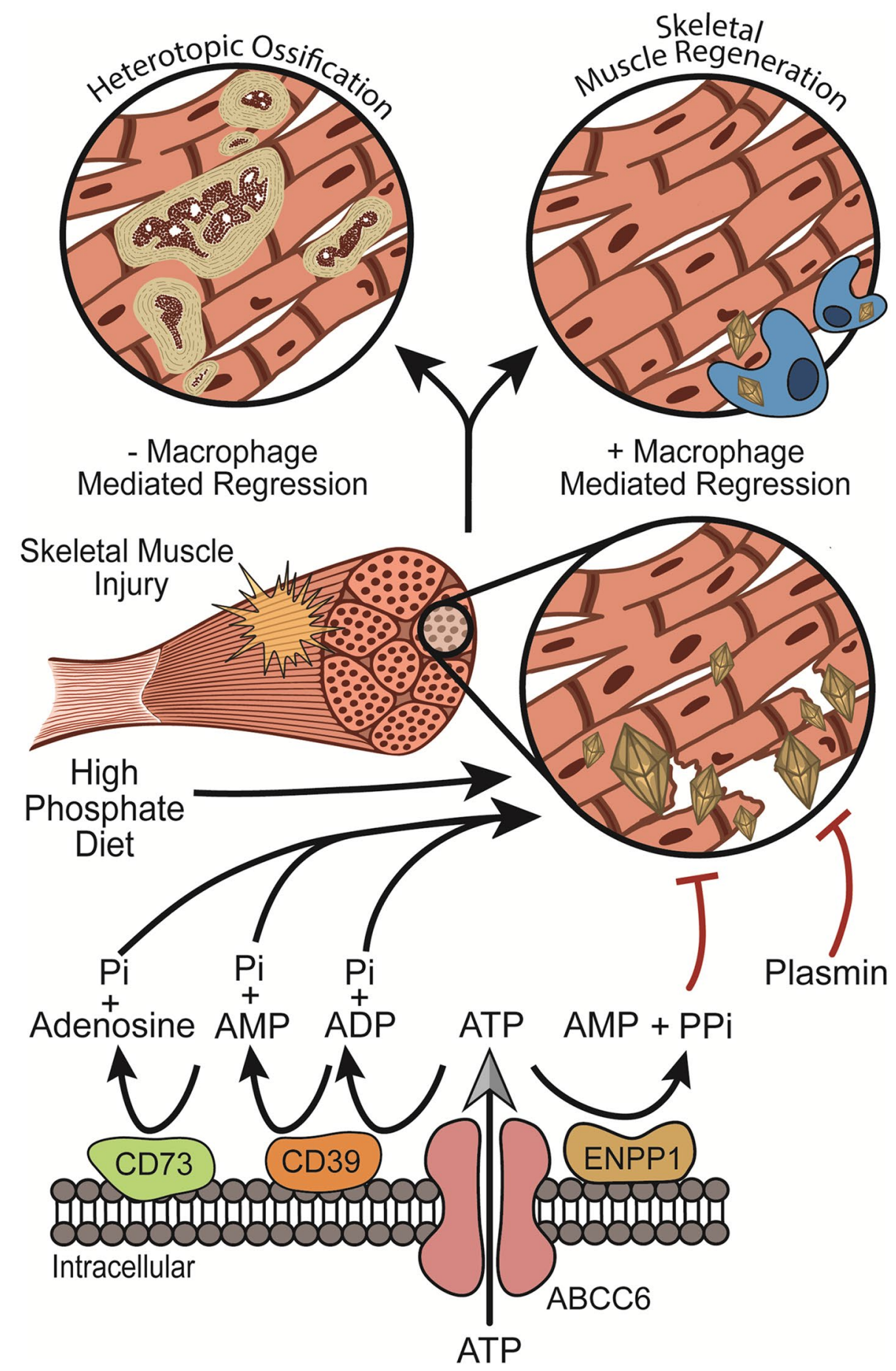

likewise target physiologic bone leading to adverse effects on bone regeneration and bone health [66-69]. Yet, by placing nanohydroxyapatite and $\mathrm{HO}$ on a pathologic continuum, this expands the number of potential pharmacologic strategies available by applying early therapeutic interventions aimed at nanohydroxyapatite in leu of mature bone. Furthermore, early intervention at the nanohydroxyapatite level potentially allows for improved preservation of physiologic bone formation. 
Acknowledgements The authors would like to thank the members of the Schoenecker Lab, in particular Lou Posey, Alex Hysong, and Deke Blum, for their assistance in critically reviewing this work. We would like to acknowledge the Vanderbilt Small Animal-Imaging Core and the Vanderbilt animal care staff for supplying and maintaining the imaging equipment and our animal facility, respectively. Finally, we would like to thank our family and colleges for their continual support, understanding, and patience as we perused these scientific endeavors. Funding for this work was provided by the Vanderbilt University Medical Center Department of Orthopaedics and Rehabilitation (JGS), the Caitlin Lovejoy Fund (JGS), and the James O'Loughlin PXE Research Fund through PXE International. Use of the Translational Pathology Shared Resource was supported by NCI/NIH Cancer Center Support Grant (2P30 CA068485-14) and the Vanderbilt Mouse Metabolic Phenotyping Center Grant (5U24DK059637-13). $\mu$ CT imaging and analysis were supported in part by the Center for Small Animal Imaging at the Vanderbilt University Institute of Imaging Sciences (S10RR027631) from the NIH. SNM was supported by T32GM007628 pre-doctoral pharmacology training grant. Funding sources for this project had no involvement in study design, collection and analysis of data, writing of the report, or decision in submitting this article for publication.

Author Contributions Study concept and design: SNML, QL, ST, RJG, JMMC, JU, and JGS. Acquisition of data: SNML, QL, BHYG, JTM, GDH, THA, MS, and ST. Analysis of data: SNML, BHYG, JTM, GDH, MS, ST, JMMC, JU, and JGS. Providing reagent or animals: QL, THA, ST, RJG, JU, and JGS. Manuscript drafting: SNML, GDH, ST, and JGS. Figure production: SNML, QL, BHYG, JTM, ST, JMMC, and JGS. Critical revisions: QL, BHYG, JTM, RJG, JMMC, JU, and JGS. Providing funding and support: HSS, JU, and JGS. All authors revised the paper critically for intellectual content and approved the final version. All authors agree to be accountable for the work and to ensure that any questions relating to the accuracy and integrity of the paper are investigated and properly resolved.

\section{Compliance with Ethical Standards}

Conflict of interest Jonathan G. Schoenecker is a member of the education advisory board at OrthoPediatrics and receives research funding from OrthoPediatrics and research support from IONIS Pharmaceuticals. Jonathan G. Schoenecker receives research support from PXE International. Stephanie N. Moore-Lotridge, Qiaoli Li, Breanne H. Y. Gibson, Joseph T. Martin, Gregory D. Hawley, Thomas H. Arnold, Masanori Saito, Sami Tannouri, Herbert S. Schwartz, Richard J. Gumina, Justin M.M. Cates, Jouni Uitto, and Jonathan G. Schoenecker have declared that no conflict of interest exists.

Human and Animal Rights and Informed Consent All animal procedures were approved by the Vanderbilt University IACUC (M1600225). All procedures performed in studies involving animals were in accordance with the ethical standards of the institution at which the studies were conducted. Welfare-related assessments were carried out prior to and throughout all experiments by trained personnel at Vanderbilt University and Vanderbilt University Medical Center. This article does not contain any studies with human participants performed by any of the authors.

Open Access This article is distributed under the terms of the Creative Commons Attribution 4.0 International License (http://creativeco mmons.org/licenses/by/4.0/), which permits unrestricted use, distribution, and reproduction in any medium, provided you give appropriate credit to the original author(s) and the source, provide a link to the Creative Commons license, and indicate if changes were made.

\section{References}

1. Ranganathan K, Loder S, Agarwal S, Wong VW, Forsberg J, Davis TA, Wang S, James AW, Levi B (2015) Heterotopic ossification: basic-science principles and clinical correlates. J Bone Joint Surg Am 97(13):1101-1111. https://doi.org/10.2106/JBJS.N.01056

2. Nauth A, Giles E, Potter BK, Nesti LJ, O’Brien FP, Bosse MJ, Anglen JO, Mehta S, Ahn J, Miclau T, Schemitsch EH (2012) Heterotopic ossification in orthopaedic trauma. J Orthop Trauma 26(12):684-688. https://doi.org/10.1097/BOT.0b013e318272462 4

3. Garland DE (1988) Clinical observations on fractures and heterotopic ossification in the spinal cord and traumatic brain injured populations. Clin Orthop Relat Res (233):86-101

4. Giannoudis PV, Grotz MR, Papakostidis C, Dinopoulos H (2005) Operative treatment of displaced fractures of the acetabulum. A meta-analysis. J Bone Joint Surg Br 87(1):2-9

5. Dey D, Wheatley BM, Cholok D, Agarwal S, Yu PB, Levi B, Davis TA (2017) The traumatic bone: trauma-induced heterotopic ossification. Transl Res 186:95-111. https://doi.org/10.1016/j. trs1.2017.06.004

6. Forsberg JA, Pepek JM, Wagner S, Wilson K, Flint J, Andersen RC, Tadaki D, Gage FA, Stojadinovic A, Elster EA (2009) Heterotopic ossification in high-energy wartime extremity injuries: prevalence and risk factors. J Bone Joint Surg Am 91(5):10841091. https://doi.org/10.2106/JBJS.H.00792

7. Chalmers J, Gray DH, Rush J (1975) Observations on the induction of bone in soft tissues. J Bone Joint Surg Br 57(1):36-45

8. Kaplan FS, Xu M, Seemann P, Connor JM, Glaser DL, Carroll L, Delai P, Fastnacht-Urban E, Forman SJ, Gillessen-Kaesbach G, Hoover-Fong J, Koster B, Pauli RM, Reardon W, Zaidi SA, Zasloff M, Morhart R, Mundlos S, Groppe J, Shore EM (2009) Classic and atypical fibrodysplasia ossificans progressiva (FOP) phenotypes are caused by mutations in the bone morphogenetic protein (BMP) type I receptor ACVR1. Hum Mutat 30(3):379390. https://doi.org/10.1002/humu.20868

9. Shore EM, Kaplan FS (2011) Role of altered signal transduction in heterotopic ossification and fibrodysplasia ossificans progressiva. Curr Osteoporos Rep 9(2):83-88. https://doi.org/10.1007/s1191 4-011-0046-3

10. Mitchell EJ, Canter J, Norris P, Jenkins J, Morris J (2010) The genetics of heterotopic ossification: insight into the bone remodeling pathway. J Orthop Trauma 24(9):530-533. https://doi. org/10.1097/BOT.0b013e3181ed147b

11. Boonrungsiman S, Gentleman E, Carzaniga R, Evans ND, McComb DW, Porter AE, Stevens MM (2012) The role of intracellular calcium phosphate in osteoblast-mediated bone apatite formation. Proc Natl Acad Sci USA 109(35):14170-14175. https ://doi.org/10.1073/pnas.1208916109

12. Moore SN, Tanner SB, Schoenecker JG (2015) Bisphosphonates: from softening water to treating PXE. Cell Cycle 14(9):13541355. https://doi.org/10.1080/15384101.2015.1024585

13. Jahnen-Dechent W, Schafer C, Ketteler M, McKee MD (2008) Mineral chaperones: a role for fetuin-A and osteopontin in the inhibition and regression of pathologic calcification. J Mol Med (Berl) 86(4):379-389. https://doi.org/10.1007/s00109-007-0294-y

14. Brylka L, Jahnen-Dechent W (2013) The role of fetuin-A in physiological and pathological mineralization. Calcif Tissue Int 93(4):355-364. https://doi.org/10.1007/s00223-012-9690-6

15. Cuervo LA, Pita JC, Howell DS (1971) Ultramicroanalysis of $\mathrm{pH}, \mathrm{p} \mathrm{CO} 2$ and carbonic anhydrase activity at calcifying sites in cartilage. Calcif Tissue Res 7(3):220-231

16. Dabisch-Ruthe M, Kuzaj P, Gotting C, Knabbe C, Hendig D (2014) Pyrophosphates as a major inhibitor of matrix calcification 
in Pseudoxanthoma elasticum. J Dermatol Sci 75(2):109-120. https://doi.org/10.1016/j.jdermsci.2014.04.015

17. Giachelli CM (2005) Inducers and inhibitors of biomineralization: lessons from pathological calcification. Orthod Craniofac Res 8(4):229-231. https://doi.org/10.1111/j.1601-6343.2005.00345.x

18. Hendig D, Schulz V, Arndt M, Szliska C, Kleesiek K, Gotting C (2006) Role of serum fetuin-A, a major inhibitor of systemic calcification, in pseudoxanthoma elasticum. Clin Chem 52(2):227234. https://doi.org/10.1373/clinchem.2005.059253

19. Hendig D, Zarbock R, Szliska C, Kleesiek K, Gotting C (2008) The local calcification inhibitor matrix Gla protein in pseudoxanthoma elasticum. Clin Biochem 41(6):407-412. https://doi. org/10.1016/j.clinbiochem.2007.12.023

20. Jahnen-Dechent W, Heiss A, Schafer C, Ketteler M (2011) Fetuin-A regulation of calcified matrix metabolism. Circ Res 108(12):1494-1509. https://doi.org/10.1161/CIRCRESAHA 110.234260

21. Jahnen-Dechent W, Schinke T, Trindl A, Muller-Esterl W, Sablitzky F, Kaiser S, Blessing M (1997) Cloning and targeted deletion of the mouse fetuin gene. J Biol Chem 272(50):31496-31503

22. Jiang Q, Li Q, Uitto J (2007) Aberrant mineralization of connective tissues in a mouse model of pseudoxanthoma elasticum: systemic and local regulatory factors. J Invest Dermatol 127(6):13921402. https://doi.org/10.1038/sj.jid.5700729

23. Li Q, Price TP, Sundberg JP, Uitto J (2014) Juxta-articular jointcapsule mineralization in CD73 deficient mice: similarities to patients with NT5E mutations. Cell Cycle 13(16):2609-2615. https://doi.org/10.4161/15384101.2014.943567

24. Li Q, Uitto J (2013) Mineralization/anti-mineralization networks in the skin and vascular connective tissues. Am J Pathol 183(1):10-18. https://doi.org/10.1016/j.ajpath.2013.03.002

25. Schafer C, Heiss A, Schwarz A, Westenfeld R, Ketteler M, Floege J, Muller-Esterl W, Schinke T, Jahnen-Dechent W (2003) The serum protein alpha 2-Heremans-Schmid glycoprotein/ fetuin-A is a systemically acting inhibitor of ectopic calcification. J Clin Invest 112(3):357-366. https://doi.org/10.1172/ JCI17202

26. Sly WS, Whyte MP, Sundaram V, Tashian RE, Hewett-Emmett D, Guibaud P, Vainsel M, Baluarte HJ, Gruskin A, Al-Mosawi $M$ et al (1985) Carbonic anhydrase II deficiency in 12 families with the autosomal recessive syndrome of osteopetrosis with renal tubular acidosis and cerebral calcification. N Engl J Med 313(3):139-145. https://doi.org/10.1056/NEJM198507183130302

27. Steitz SA, Speer MY, McKee MD, Liaw L, Almeida M, Yang H, Giachelli CM (2002) Osteopontin inhibits mineral deposition and promotes regression of ectopic calcification. Am J Pathol 161(6):2035-2046. https://doi.org/10.1016/S0002-9440(10)64482 $-3$

28. Westenfeld R, Schafer C, Smeets R, Brandenburg VM, Floege J, Ketteler M, Jahnen-Dechent W (2007) Fetuin-A (AHSG) prevents extraosseous calcification induced by uraemia and phosphate challenge in mice. Nephrol Dial Transplant 22(6):1537-1546. https:// doi.org/10.1093/ndt/gfm094

29. Yuan Q, Jiang Y, Zhao X, Sato T, Densmore M, Schuler C, Erben RG, McKee MD, Lanske B (2014) Increased osteopontin contributes to inhibition of bone mineralization in FGF23-deficient mice. J Bone Miner Res 29(3):693-704. https://doi.org/10.1002/ jbmr.2079

30. Dabisch-Ruthe M, Brock A, Kuzaj P, Charbel Issa P, Szliska C, Knabbe C, Hendig D (2014) Variants in genes encoding pyrophosphate metabolizing enzymes are associated with pseudoxanthoma elasticum. Clin Biochem 47(15):60-67. https://doi.org/10.1016/j. clinbiochem.2014.07.003

31. Jansen RS, Duijst S, Mahakena S, Sommer D, Szeri F, Varadi A, Plomp A, Bergen AA, Oude Elferink RP, Borst P, van de Wetering
$\mathrm{K}$ (2014) ABCC6-mediated ATP secretion by the liver is the main source of the mineralization inhibitor inorganic pyrophosphate in the systemic circulation-brief report. Arterioscler Thromb Vasc Biol 34(9):1985-1989. https://doi.org/10.1161/ATVBA HA.114.304017

32. Li Q, Berndt A, Guo H, Sundberg JP, Uitto J (2012) A novel animal model for pseudoxanthoma elasticum: the KK/HIJ mouse. Am J Pathol 181(4):1190-1196. https://doi.org/10.1016/j.ajpat h.2012.06.014

33. Jiang Q, Oldenburg R, Otsuru S, Grand-Pierre AE, Horwitz EM, Uitto J (2010) Parabiotic heterogenetic pairing of Abcc6-/-/ Rag1-/- mice and their wild-type counterparts halts ectopic mineralization in a murine model of pseudoxanthoma elasticum. Am J Pathol 176(4):1855-1862. https://doi.org/10.2353/ajpat h. 2010.090983

34. Li Q, Kingman J, van de Wetering K, Tannouri S, Sundberg JP, Uitto J (2017) Abcc6 knockout rat model highlights the role of liver in PPi homeostasis in pseudoxanthoma elasticum. J Invest Dermatol 137(5):1025-1032. https://doi.org/10.1016/j. jid.2016.11.042

35. Ziegler SG, Ferreira CR, MacFarlane EG, Riddle RC, Tomlinson RE, Chew EY, Martin L, Ma CT, Sergienko E, Pinkerton AB, Millan JL, Gahl WA, Dietz HC (2017) Ectopic calcification in pseudoxanthoma elasticum responds to inhibition of tissue-nonspecific alkaline phosphatase. Sci Transl Med 9 (393):eaal1669. https:// doi.org/10.1126/scitranslmed.aal1669

36. Mignemi NA, Yuasa M, Baker CE, Moore SN, Ihejirika RC, Oelsner WK, Wallace CS, Yoshii T, Okawa A, Revenko AS, MacLeod AR, Bhattacharjee G, Barnett JV, Schwartz HS, Degen JL, Flick MJ, Cates JM, Schoenecker JG (2017) Plasmin prevents dystrophic calcification after muscle injury. J Bone Miner Res 32(2):294-308. https://doi.org/10.1002/jbmr.2973

37. Moore SN, Hawley GD, Smith EN, Mignemi NA, Ihejirika RC, Yuasa M, Cates JM, Liu X, Schoenecker JG (2016) Validation of a radiography-based quantification designed to longitudinally monitor soft tissue calcification in skeletal muscle. PLoS ONE 11(7):e0159624. https://doi.org/10.1371/journal.pone.0159624

38. van Rooijen N (2008) Liposomes for targeting of antigens and drugs: immunoadjuvant activity and liposome-mediated depletion of macrophages. J Drug Target 16(7):529-534. https://doi. org/10.1080/10611860802228426

39. van Rooijen N, Bakker J, Sanders A (1997) Transient suppression of macrophage functions by liposome-encapsulated drugs. Trends Biotechnol 15(5):178-185

40. Russell RG (2011) Bisphosphonates: the first 40 years. Bone 49(1):2-19. https://doi.org/10.1016/j.bone.2011.04.022

41. Fleisch H, Bisaz S (1962) Isolation from urine of pyrophosphate, a calcification inhibitor. Am J Physiol 203:671-675. https://doi. org/10.1152/ajplegacy.1962.203.4.671

42. Russell RG, Hodgkinson A (1966) The urinary excretion of inorganic pyrophosphate by normal subjects and patients with renal calculus. Clin Sci 31(1):51-62

43. Barker LM, McPhillips JJ, Lawrence GD, Doty SB, Pallante SL, Bills CE, Scott WW Jr, Howard JE (1970) Studies on mechanisms of calcification. I. Properties of urinary derivatives which inhibit cartilage calcification. II. Electron microscopic observations of the effect of inhibitors in crystal formation. Johns Hopkins Med J 127(1):2-22

44. Uitto J, Bercovitch L, Terry SF, Terry PF (2011) Pseudoxanthoma elasticum: progress in diagnostics and research towards treatment: summary of the 2010 PXE International Research Meeting. Am J Med Genet A 155A(7):1517-1526. https://doi.org/10.1002/ ajmg.a.34067

45. Wang Y, Wan C, Deng L, Liu X, Cao X, Gilbert SR, Bouxsein ML, Faugere MC, Guldberg RE, Gerstenfeld LC, Haase VH, Johnson RS, Schipani E, Clemens TL (2007) The hypoxia-inducible 
factor alpha pathway couples angiogenesis to osteogenesis during skeletal development. J Clin Invest 117(6):1616-1626. https://doi. org/10.1172/JCI31581

46. Hiemstra PS (2013) Altered macrophage function in chronic obstructive pulmonary disease. Ann Am Thorac Soc 10(Suppl):S180-185. https://doi.org/10.1513/AnnalsATS.20130 5-123AW

47. Bories G, Caiazzo R, Derudas B, Copin C, Raverdy V, Pigeyre M, Pattou F, Staels B, Chinetti-Gbaguidi G (2012) Impaired alternative macrophage differentiation of peripheral blood mononuclear cells from obese subjects. Diab Vasc Dis Res 9(3):189-195. https ://doi.org/10.1177/1479164111430242

48. Liang Z, Zhang Q, Thomas CM, Chana KK, Gibeon D, Barnes PJ, Chung KF, Bhavsar PK, Donnelly LE (2014) Impaired macrophage phagocytosis of bacteria in severe asthma. Respir Res 15:72. https://doi.org/10.1186/1465-9921-15-72

49. Fernandez-Boyanapalli R, McPhillips KA, Frasch SC, Janssen WJ, Dinauer MC, Riches DW, Henson PM, Byrne A, Bratton DL (2010) Impaired phagocytosis of apoptotic cells by macrophages in chronic granulomatous disease is reversed by IFN-gamma in a nitric oxide-dependent manner. J Immunol 185(7):4030-4041. https://doi.org/10.4049/jimmunol.1001778

50. Schrijvers DM, De Meyer GR, Kockx MM, Herman AG, Martinet W (2005) Phagocytosis of apoptotic cells by macrophages is impaired in atherosclerosis. Arterioscler Thromb Vasc Biol 25(6):1256-1261. https://doi.org/10.1161/01.ATV.0000166517 .18801.a7

51. Kobayashi M, Takahashi H, Sanford AP, Herndon DN, Pollard RB, Suzuki F (2002) An increase in the susceptibility of burned patients to infectious complications due to impaired production of macrophage inflammatory protein $1 \alpha$. J Immunol 169(8):44604466. https://doi.org/10.4049/jimmunol.169.8.4460

52. Herlihy JP, Vermeulen MW, Joseph PM, Hales CA (1995) Impaired alveolar macrophage function in smoke inhalation injury. J Cell Physiol 163(1):1-8. https://doi.org/10.1002/ jcp.1041630102

53. Markello TC, Pak LK, St Hilaire C, Dorward H, Ziegler SG, Chen MY, Chaganti K, Nussbaum RL, Boehm M, Gahl WA (2011) Vascular pathology of medial arterial calcifications in NT5E deficiency: implications for the role of adenosine in pseudoxanthoma elasticum. Mol Genet Metab 103(1):44-50. https://doi. org/10.1016/j.ymgme.2011.01.018

54. Szabó Z, Váradi A, Li Q, Uitto J (2011) ABCC6 does not transport adenosine-relevance to pathomechanism of pseudoxanthoma elasticum. Mol Genet Metab 104(3):421. https://doi.org/10.1016/j. ymgme.2011.07.013

55. Leftheriotis G, Vanakker O, Le Saux O, Martin L (2011) Reply to the article of C. Markello et al. entitled "Vascular pathology of medial arterial calcifications in NT5E deficiency: implications for the role of adenosine in pseudoxanthoma elasticum". Mol Genet Metab 103(2):199-200. https://doi.org/10.1016/j.ymgme .2011 .03 .014

56. Markello TC, St Hilaire C, Ziegler SG, Nussbaum RL, Boehm M, Gahl WA (2011) Reply to Professor Leftheriotis et al. Mol Genet Metab 103(3):305. https://doi.org/10.1016/j.ymgme.2011.04.008

57. Zhao J, Kingman J, Sundberg JP, Uitto J, Li Q (2017) Plasma PPi deficiency is the major, but not the exclusive, cause of ectopic mineralization in an Abcc6(-/-) mouse model of PXE. J Invest Dermatol 137(11):2336-2343. https://doi.org/10.1016/j. jid.2017.06.006

58. Yegutkin GG, Marttila-Ichihara F, Karikoski M, Niemela J, Laurila JP, Elima K, Jalkanen S, Salmi M (2011) Altered purinergic signaling in CD73-deficient mice inhibits tumor progression. Eur $\mathbf{J}$ Immunol 41(5):1231-1241. https://doi.org/10.1002/eji.201041292

59. Dedinszki D, Szeri F, Kozak E, Pomozi V, Tokesi N, Mezei TR, Merczel K, Letavernier E, Tang E, Le Saux O, Aranyi T, van de Wetering K, Varadi A (2017) Oral administration of pyrophosphate inhibits connective tissue calcification. EMBO Mol Med 9(11):1463-1470. https://doi.org/10.15252/emmm.201707532

60. Convente MR, Chakkalakal SA, Yang E, Caron RJ, Zhang D, Kambayashi T, Kaplan FS, Shore EM (2018) Depletion of mast cells and macrophages impairs heterotopic ossification in an Acvr1(R206H) mouse model of fibrodysplasia ossificans progressiva. J Bone Miner Res 33(2):269-282. https://doi.org/10.1002/ jbmr.3304

61. Genet F, Kulina I, Vaquette C, Torossian F, Millard S, Pettit AR, Sims NA, Anginot A, Guerton B, Winkler IG, Barbier V, Lataillade JJ, Le Bousse-Kerdiles MC, Hutmacher DW, Levesque JP (2015) Neurological heterotopic ossification following spinal cord injury is triggered by macrophage-mediated inflammation in muscle. J Pathol 236(2):229-240. https://doi.org/10.1002/path.4519

62. Milde R, Ritter J, Tennent GA, Loesch A, Martinez FO, Gordon S, Pepys MB, Verschoor A, Helming L (2015) Multinucleated giant cells are specialized for complement-mediated phagocytosis and large target destruction. Cell Rep 13(9):1937-1948. https://doi. org/10.1016/j.celrep.2015.10.065

63. Chambers TJ (1981) Phagocytic recognition of bone by macrophages. J Pathol 135(1):1-7. https://doi.org/10.1002/path.17113 50102

64. Villa-Bellosta R, Hamczyk MR, Andres V (2016) Alternatively activated macrophages exhibit an anticalcifying activity dependent on extracellular ATP/pyrophosphate metabolism. Am J Physiol Cell Physiol 310(10):C788-C799. https://doi.org/10.1152/ ajpcell.00370.2015

65. Villa-Bellosta R, Hamczyk MR, Andres V (2017) Novel phosphate-activated macrophages prevent ectopic calcification by increasing extracellular ATP and pyrophosphate. PLoS ONE 12(3):e0174998. https://doi.org/10.1371/journal.pone.0174998

66. Tsuji K, Bandyopadhyay A, Harfe BD, Cox K, Kakar S, Gerstenfeld L, Einhorn T, Tabin CJ, Rosen V (2006) BMP2 activity, although dispensable for bone formation, is required for the initiation of fracture healing. Nat Genet 38(12):1424-1429. https://doi. org/10.1038/ng 1916

67. Cooley LM, Goss RJ (1958) The effects of transplantation and $\mathrm{x}$-irradiation on the repair of fractured bones. Am J Anat 102(2):167-181. https://doi.org/10.1002/aja.1001020202

68. De Luca F, Uyeda JA, Mericq V, Mancilla EE, Yanovski JA, Barnes KM, Zile MH, Baron J (2000) Retinoic acid is a potent regulator of growth plate chondrogenesis. Endocrinology 141(1):346-353. https://doi.org/10.1210/endo.141.1.7283

69. Li J, Mori S, Kaji Y, Kawanishi J, Akiyama T, Norimatsu H (2000) Concentration of bisphosphonate (incadronate) in callus area and its effects on fracture healing in rats. J Bone Miner Res 15(10):2042-2051. https://doi.org/10.1359/jbmr.2000.15.10.2042 